\title{
A Clinical Trial of Sulforthomidine* ('Fanasil' Roche) in Lepromatous Leprosy
}

\author{
G. GURRIE, м.в.сн.в. (Glas.), D.т.м. \& H. (edin.) \\ Formerly Government Leprologist and Acting Director \\ of the LEPRA Control Project in Malawi \\ Present address : 4 Peel Terrace, Edinburgh 9, Scotland
}

Sulforthomidine ('Fanasil' Roche) is 4-sulphanilamido-5,6-dimethoxypyrimidine, a longacting sulphonamide which has low toxicity and good antibacterial efficacy. As the half-life of this drug exceeds I oo hours in the majority of humans it need only be given once a week. The concentration of sulforthomidine in the skin is comparatively high (about $\mathrm{I} / 3$ of the plasma concentration) and the drug has proved useful in a number of bacterial skin infections including leprosy. Sulforthomidine, supplied by Roche Products Limited in the form of $500 \mathrm{mg}$. 'Fanasil' tablets, was subjected to a clinical trial in human leprosy.

\section{Selection of Patients}

Thirty-two patients suffering from lepromatous leprosy and lepromin-negative were selected of whom two absconded during the trial period, both in the control group. All patients had received dapsone for a short period ( 2 to I 2 weeks) prior to the clinical trial and all patients resumed dapsone at the end of the six month trial period. Of the 30 patients who completed the trial $\mathrm{i} 6$ received sulforthomidine $\mathrm{I} g$. once a week and $\mathrm{I} 4$ received dapsone $0.3 \mathrm{~g}$. twice a week, serving as a control. Ideally patients submitted to trial should not have had previous treatment (Jopling, I 965) but a large number of new untreated cases can seldom be collected at one leprosarium and the selection of cases already treated for a short time with dapsone permits interesting comparisons.

\section{Methods of Assessment}

Biopsies were taken and smears were made from both ear lobes and from the sites of the biopsies. Local anaesthesia was used to permit adequate incision and scraping of the dermis which can be difficult in nervous patients. The Bacterial Index ( $\mathrm{I}-6$ plus) was assessed by the method of Ridley (I958) and the Biopsy Index and Granularity Index established, also by the methods of Ridley ( I 964), both at the beginning and at the end of the six month trial period. Patients were observed twice a week throughout the trial and special attention was given to the incidence of erythema nodosum leprosum (ENL) and of side effects of the drugs. The progress of the sulforthomidine and dapsone groups is set out in the following tables.

Results

TABLE I

Bacterial Index, assessed I to 6 plus

(Ridley, r 958)

\begin{tabular}{ccc}
\hline Before & After & Im- \\
Trial & Trial & provement \\
\hline
\end{tabular}

\section{Sulforthomidine}

\begin{tabular}{llll}
$\begin{array}{l}\text { Group, } \\
\text { I } 6 \text { patients }\end{array}$ & $4 \cdot 7$ & $4 \cdot \mathrm{I}$ & I $3 \%$ \\
$\begin{array}{l}\text { Dapsone Group } \\
\text { I } 4 \text { patients }\end{array}$ & $4 \cdot 3$ & $3 \cdot 9$ & $9 \%$ \\
\hline
\end{tabular}

TAB L E 2

Percentage of Dermis occupied by Granuloma

\begin{tabular}{lccc}
\hline & $\begin{array}{c}\text { Before } \\
\text { Trial }\end{array}$ & $\begin{array}{c}\text { After } \\
\text { Trial }\end{array}$ & $\begin{array}{c}\text { Im- } \\
\text { provement }\end{array}$ \\
\hline $\begin{array}{l}\text { Sulforthomidine } \\
\text { Group, }\end{array}$ & $22 \cdot 7 \%$ & I I $\cdot 0 \%$ & $51 \%$ \\
I6 patients \\
$\begin{array}{l}\text { Dapsone Group } \\
\text { I } 4 \text { patients }\end{array}$ & $24 \cdot 0 \%$ & I $0 \cdot 5 \%$ & $56 \%$ \\
\hline
\end{tabular}

*The B.P. Commission approved name is sulphormethoxine. 
TABLE 3

\section{Biopsy Index}

Product of Bacterial Index $x$ Percentage of Dermis occupied by Granuloma (Ridley, I964)

\begin{tabular}{lccc}
\hline & $\begin{array}{c}\text { Before } \\
\text { Trial }\end{array}$ & $\begin{array}{c}\text { After } \\
\text { Trial }\end{array}$ & $\begin{array}{c}\text { Im- } \\
\text { provement }\end{array}$ \\
\hline $\begin{array}{l}\text { Sulforthomidine } \\
\begin{array}{l}\text { Group, } \\
\text { I6 patients }\end{array}\end{array}$ & $\mathrm{I} \cdot 07$ & $0 \cdot 45$ & $58 \%$ \\
$\begin{array}{l}\text { Dapsone Group } \\
\text { I } 4 \text { patients }\end{array}$ & $\mathrm{I} \cdot 03$ & $0 \cdot 4 \mathrm{I}$ & $60 \%$ \\
\hline
\end{tabular}

TABLE 4

\section{Granularity Index}

The Percentage of Bacilli Exhibiting Irregular Staining Granularity (Ridley, I964)

\begin{tabular}{lccc}
\hline & $\begin{array}{c}\text { Before } \\
\text { Trial }\end{array}$ & $\begin{array}{c}\text { After } \\
\text { Trial }\end{array}$ & $\begin{array}{c}\text { Im- } \\
\text { provement }\end{array}$ \\
\hline $\begin{array}{l}\text { Sulforthomidine } \\
\text { Group, }\end{array}$ & $85 \%$ & $98 \%$ & $\mathrm{I} 5 \%$ \\
$\begin{array}{l}\text { I } 6 \text { patients } \\
\text { I } 4 \text { patients }\end{array}$ & $84 \%$ & $95 \%$ & $\mathrm{I} 3 \%$ \\
\hline
\end{tabular}

It will be noted from the above Tables i to 4 that there is no significant difference in the rate of bacteriological improvement in the two groups.

\section{Side Effects}

As already stated all patients received dapsone for a short time prior to the trial. This permitted the incidence of side effects attributable to dapsone to be assessed in all patients.

During the six month trial period the incidence of side effects to sulforthomidine and to dapsone respectively was noted, and the results are recorded in Tables 5 and 6 below. It will be seen that during the first month of dapsone therapy about $75 \%$ of the patients experienced side effects attributable to the drug. In the control group, after persevering with dapsone, the incidence gradually fell to about $25 \%$ over the six month period. In the trial group, however, when the regime was changed to sulforthomidine, the side effects ceased with relative abruptness (i.e. within one week) and only one patient out of i 6 admitted to any side effects at all. This patient had suffered from neuritis while receiving dapsone prior to instituting sulforthomidine and it was not certain that the 'burning' sensation which he experienced could be attributed to sulforthomidine. In this trial, therefore, sulforthomidine proved singularly free from side effects.

The difference between the control group and the sulforthomidine group was more striking than Table 7 indicates. The ENL in the sulforthomidine group was mild. In the dapsone group not only were 8 patients $(57 \%)$ affected, but 4 of these were severe and 2 were grave patients. One of the latter exhibited Lucio-like sloughing of the lesions. In this small series, therefore, sulforthomidine showed no tendency to exacerbate ENL. This was also the experience of Wilkinson and Barclay (1964) who treated 33 lepromatous patients with sulforthomidine for periods varying from six months to three years. They comment that this drug appeared less prone to give rise to leprotic reactions than other anti-leprosy drugs and could even be administered during reactional phases.

\section{Other Complications}

Four patients had mild neuritis while on dapsone therapy prior to the trial but none suffered from active neuritis during the trial and no comparison can be made. Two patients (female) were found to be suffering from endemic colloid goitre. In view of the tendency of sulphonamides to interfere with thyroxine synthesis these patients were watched carefully. No aggravation of the goitre occurred. Another 2 female patients in the sulforthomidine group were pregnant. Their pregnancies and deliveries were uneventful, and there was no exacerbation during the subsequent six months of lactation.

As sulforthomidine has been shown to be a potent schizonticide in falciparum malaria (Laing, I965) and dapsone also has antimalarial properties (Archibald and Ross, i 960) it was considered of interest to examine blood films for malaria parasites. Thick and thin films were taken from all patients in the first and in the sixth month of the trial. Scanty ring forms resembling Plasmodium falciparum (three parasites per I oo thick film fields) were found in one patient only in the first month while receiving sulforthomidine. No parasites were found in any other patient whether on dapsone or sulforthomidine. 
TABLE 5

Incidence of Side Effects

Prior to Trial

During Trial

I patient

$(6 \%)$

Sulforthomidine

I g. once a week

twice a week

I I patients

$$
(78 \%)
$$

I 4 patients

Dapsone $0 \cdot 3 \mathrm{~g}$.

twice a week

4 patients

Dapsone $0 \cdot 3 \mathrm{~g}$.

twice a week
Reduction in incidence of side effects
$(28 \%)$
$64 \%$

TABLE 6

\section{Type of Side Effect and Number of Patients Complaining of Each Side Effect}

\begin{tabular}{cccc}
\multicolumn{2}{c}{ Before Trial } & \multicolumn{2}{c}{ During Trial } \\
Control & Trial & Control & Trial \\
Group on & Group on & Group on & Group on \\
Dapsone & Dapsone & Dapsone & Sulforthomidine
\end{tabular}

Headache

Deep Aches

Formication

Itching

Lassitude

Abdominal Colic

Epistaxis

Dizziness

Burning

Dermatitis

Toial number of

complaints

Reduction in Incidence of

Side Effects

I 8

23

6

I

$66 \% \quad 95 \%$

TABLE 7

Incidence of Erythema Nodosum Leprosum (ENL)

$\begin{array}{ccc}\begin{array}{c}\text { Before Trial } \\ \text { (all patients }\end{array} & \text { During Trial } & \begin{array}{c}\text { After Trial } \\ \text { (all patients }\end{array} \\ \text { on dapsone) } & (6 \text { months }) & \text { on dapsone) }\end{array}$

Trial Group

I 6 patients

Control Group
2 patients

$$
(12 \%)
$$

3 patients

$$
(21 \%)
$$

2 patients (on sulforthomidine)

$$
\text { ( } 12 \% \text { ) }
$$

8 patients

(on dapsone)

$$
(57 \%)
$$

2 patients

( $12 \%$ )

6 patients

$(43 \%)$ 


\section{Clincial Progress}

The apparent improvement was greatest in the sulforthomidine group but in the absence of a double blind technique the assessment may be suspect. Improvement occurred in all patients, both subjectively felt and objectively seen, and was assessed as 'good' or 'very good' (Table $8)$.

TABLE 8

\section{Clinical Improvement}

The Number of Patients whose Improvement was Assessed as 'Very Good'

\begin{tabular}{lcc}
\hline $\begin{array}{c}\text { Patient's } \\
\text { Assessment } \\
\text { (subjective) }\end{array}$ & $\begin{array}{r}\text { Clinician's } \\
\text { Assessment } \\
\text { (objective) }\end{array}$ \\
\hline $\begin{array}{l}\text { Sulforthomidine } \\
\text { Group, }\end{array}$ & Io patients & I4 patients \\
I6 patients & $(62 \%)$ & $(88 \%)$ \\
Dapsone Group & 7 patients & 7 patients \\
I 4 patients & $(50 \%)$ & $(50 \%)$ \\
\hline
\end{tabular}

The clinical improvement in the dapsone group was obscured by a greater tendency to ENL reactions and assessment was often difficult especially when focal exacerbations of ENL co-existed with appreciable general subsidence of leprous infiltration. All that can be said is that the clinical progress with sulforthomidine is as good as that achieved with dapsone.

\section{Sumimary and Conclusions}

Sixteen lepromatous leprosy patients were submitted to a six month clinical trial of sulforthomidine ('Fanasil' Roche), a long-acting sulphonamide administered orally in a dosage schedule of I g. once a week. A control group of I 4 patients received dapsone $0 \cdot 3 \mathrm{~g}$. twice a week.
The clinical and bacteriological progress of the patients on sulforthomidine was as good as that achieved by dapsone. The incidence and severity of ENL reactions and the incidence of side effects attributable to the drug were much less in the sulforthomidine group than in the dapsone group. From this limited trial it appears that sulforthomidine is an effective anti-leprosy drug singularly free from side effects and reactions.

\section{ACKNOWLEDGEMENTS}

I wish to thank Roche Products Limited for supplies of 'Fanasil' and in particular Dr John Garrod of their Department of Clinical Research for providing information and for his constructive criticism. I am grateful also to Dr R. Park, Permanent Secretary, Ministry of Health, Malawi, for permission to publish this paper.

The B.P. Co m. approved name is sulphormethoxine Outside the United Kingdo drug is, however, known as sulforthomidine.

\section{R E F E R E N C ES}

ARchibald, H. м. and ross, c. м. (i 96o). 7. Trop. Med. Hyg., $63: 25$.

JOPLING, w. H. (1965). Basic principles in carrying out a pilot therapeutic trial in leprosy. Leprosy Review, $\mathbf{3 6}^{6}$ (2) : 69-7I.

LAING, A. B. G. (I965). Treatment of acute falciparum malaria with sulphorthodimethoxine (Fanasil). Brit. Med. 7., I : 905-907.

RIDLEY, D. S. (1958). Therapeutic trials in leprosy using serial biopsies. Leprosy Review, 29 : 45-52.

- ( I 964). 'Leprosy in theory and practice.' pp. 620-622, Ed. Cochrane, R. G. \& Davey, T. F., Bristol : John Wright \& Sons Ltd.

WILKINSON, F. F. and BARCLAY, c. (i 964). Treatment of leprosy with Ro 4-4393, a prolonged action sulphonamide administered in a once weekly dose : (in Spanish). Paper read at Argentinian Leprosy Congress, Carlos Paz (Pcia. de Cordoba), August, i 964. 